JDHT Journal of Dental Hygiene and Therapy

Volume 2, Nomor 2 Tahun 2021

ISSN (online) : 2723-1607 DOI: 10.36082/jdht.v2i2.337

\title{
SENAM WAJAH TERHADAP KECEPATAN ALIRAN SALIVA PADA LANSIA SEBAGAI UPAYA PENCEGAHAN XEROSTOMIA
}

\begin{tabular}{|c|c|}
\hline & $\begin{array}{c}\text { Silvia Sulistiani' }{ }^{1} \text {, Sri Wahyudi }{ }^{1} \\
{ }^{1} \text { Akademi Kesehatan Gigi Ditkesad Jakarta , Indonesia }\end{array}$ \\
\hline Info Artikel & Abstrak \\
\hline $\begin{array}{l}\text { Genesis Naskah: } \\
\text { Submitted: 2021-08-30 } \\
\text { Revised: 2021-09-27, 2021- } \\
\text { 09-30 } \\
\text { Accepted: 2021-10-04 }\end{array}$ & $\begin{array}{l}\text { Kesehatan gigi dan mulut dipengaruhi oleh saliva yang berfungsi menetralkan asam pada plak gigi, } \\
\text { sebagai lubrikasi dalam proses pengunyahan makanan, menjaga integritas gigi, sebagai pelumas } \\
\text { dan cairan pembersih yang penting bagi kesehatan rongga mulut. Saliva akan bekerja maksimal } \\
\text { ketika kecepatan aliran saliva meningkat. Gangguan aliran saliva sering terjadi pada lansia. Tujuan } \\
\text { penelitian ini adalah mengetahui pengaruh senam wajah terhadap kecepatan aliran saliva pada } \\
\text { lansia. Penelitian dilakukan pada } 30 \text { orang lanjut usia kelompok senam jantung sehat RSPAD Gatot } \\
\text { Soebroto Jakarta. Sampel saliva diambil sebelum dan sesudah senam wajah. Subyek diarahkan } \\
\text { untuk menyikat gigi, minum air, dan berpuasa selama satu jam sebelum pengambilan saliva. Data } \\
\text { penelitian dianalisis dengan menggunakan uji Wilcoxon. Kesimpulan: didapatkan nilai p-value } \\
\text { 0.006 menunjukan bahwa terdapat perbedaan kecepatan aliran saliva sebelum dan sesudah senam } \\
\text { wajah pada lansia. }\end{array}$ \\
\hline \multicolumn{2}{|c|}{$\begin{array}{l}\text { FACIAL EXERCISE ON THE FLOW VELOCITY OF SALIVA IN THE ELDERLY } \\
\text { AS XEROSTOMIA PREVENTION EFFORT }\end{array}$} \\
\hline $\begin{array}{l}\text { Keywords: } \\
\text { Saliva Flow, Facial } \\
\text { Exercise, and Elderly }\end{array}$ & $\begin{array}{l}\text { Abstract } \\
\text { Oral health is influenced by saliva which functions to neutralize acid in dental plaque, as a } \\
\text { lubricant in the process of masticating food, maintain tooth integrity, as a lubricant and cleaning } \\
\text { fluid that is important for oral health. Saliva will work best when the flow rate of saliva increases. } \\
\text { Saliva flow disorders often occur in the elderly. Facial exercises can stimulate saliva secretion and } \\
\text { oral function. The purpose of this study was to determine the effect of facial exercise on the flow } \\
\text { velocity of saliva in the elderly. The study was conducted on } 30 \text { elderlies in The Healthy Heart } \\
\text { Exercise Group at the RSPAD Gatot Soebroto Jakarta. Saliva samples were taken before and after } \\
\text { facial exercises. Subjects were directed to brush their teeth, drink water, and fasting for one hour } \\
\text { before saliva was collected. The data were analyzed using the wilcoxon test. Conclusion: the p- } \\
\text { value of } 0.006 \text { showed that there was a difference in the velocity of salivary flow before and after } \\
\text { facial exercises in the elderly. }\end{array}$ \\
\hline
\end{tabular}

Korespondensi Penulis:

Widi Nurwanti

Jl. Abdul Rahman Saleh No 18 Jakarta Pusat, Indonesia

Email: widinurwanti@gmail.com

(C) Jurusan Keperawatan Gigi Poltekkes Kemenkes Jakarta I

J1. Wijaya Kusuma No. 47-48 Cilandak Jakarta Selatan, Indonesia

email: jdht@poltekkesjakarta1.ac.id

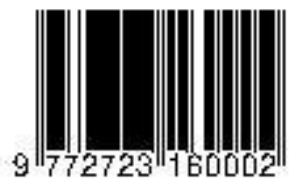




\section{Pendahuluan}

Saliva adalah komponen terpenting dalam rongga mulut (Lewapadang, 2019). Saliva dalam rongga mulut berperan dalam menetralkan asam pada plak gigi, sebagai lubrikasi dalam proses pengunyahan makanan, menjaga integritas gigi, sebagai pelumas dan sebagai cairan pembersih yang penting bagi kesehatan rongga mulut (Rahayu dan Kurniawati, 2018).

Menurut Riskesdas tahun 2013 penyakit yang paling sering diserita lansia antara lain : hipertensi 57,6\%, artritis 51,9\%, stroke 46,1\%, masalah gigi dan mulut $19,1 \%$, penyakit paru obsruktif menahun $8,6 \%$, diabetes militus $4,8 \%$. Xerostomia pada lansia dapat mempengaruhi kualitas hidup, karena adanya rasa tidak nyaman dalam rongga mulut, kesulitan dalam berbicara, bau mulut serta mempengaruhi kesehatan gigi dan mulut (Lewapadang, 2019).

Xerostomia adalah suatu keadaan mulut kering yang diakibatkan oleh adanya penurunan kecepatan sekresi saliva. Xerostomia juga identik dengan adanya sensasi subyektif dari mulut kering yang memiliki hubungan dengan penurunan produksi saliva (Rahayu dan Kurniawati, 2018). Gangguan xerostomia akibat penurunan produksi saliva pada umumnya disebabkan oleh beberapa faktor antara lain: radioterapi kepala dan leher, usia tua (lansia), penguna obat-obatan, penurunan volume kelenjar saliva, dan tingkat stress (Bartels, 2010).

Menurut Indriana (2010), sekresi saliva pada individu dapat berubah-ubah dan bersifat kondisional. Sekresi saliva minimal ketika tidak distimulasi dan meningkat ketika distimulasi, baik secara langsung oleh ujung saraf atau tidak langsung seperti stimulasi mekanis yang berupa pengunyahan, termal, dan kimiawi berupa efek pengecapan seperti rasa asam, manis, dan pahit. Pelatihan otot dapat meningkatkan kecepatan aliran saliva (Ligtenberg, Brand, Keijbus and Veerman, 2015).

Sebuah program Oral health care yang dilakukan di Jepang, terdiri dari oral health education dan oral function exercise yang dilakukan oleh Ibayashi dkk (2008) menunjukkan refleksi otototot wajah dan rongga mulut dapat menstimulus saraf otot wajah dan meningkatkan fungsi motorik

(C) Jurusan Keperawatan Gigi Poltekkes Kemenkes Jakarta I

Jl. Wijaya Kusuma No. 47-48 Cilandak Jakarta Selatan, Indonesia email: jdht@poltekkesjakarta1.ac.id pada rongga mulut (Ibayashi, Fujino, Pham and Matsuda, 2009).

Penelitian Utari (2018), menunjukan bahwa senam wajah signifikan dapat mempengaruhi stimulasi saliva yaitu sebelum senam wajah volume saliva $0,342 \mathrm{ml} / \mathrm{menit}$ dan setelah dilakukan senam wajah volume saliva menjadi $1,073 \mathrm{ml} / \mathrm{menit}$.

Berdasarkan uraian di atas, maka peneliti tertarik melakukan penelitian dengan judul "Senam Wajah terhadap Kecepatan Aliran Saliva pada Lansia sebagai Pencegahan Xerostomia".

\section{Metode}

Desain penelitian ini adalah quasi eksperimen. Populasi penelitian adalah lansia berumur 60-74 tahun pada Kelompok Senam Jantung Sehat RSPAD Gatot Soebroto, Jakarta. Pengambilan sampel mengunakan teknik total sampling dengan jumlah sampel 30 orang responden. Penelitian dilakukan di Lapangan Apel Farmasi RSPAD Gatot Soebroto.

Data diperoleh dengan melakukan pengukuran volume saliva sebelum dan sesudah responden melakukan senam wajah yaitu dengan gerakan latihan otot lidah, latihan gerakan otot wajah, dan pemijatan kelenjar saliva. Senam wajah dilaksanakan bersama-sama dengan posisi duduk tegap di kursi, rileks, kondisi tenang dan nyaman, dipandu peneliti dan diawasi oleh instruktur senam wajah.

Responden diarahkan untuk menyikat gigi, minum air, dan berpuasa selama satu jam sebelum pengambilan saliva. Sampel saliva diambil dan ditampung pada pot penampungan saliva. Saliva yang terkumpul kemudian ditimbang untuk mengetahui berat saliva sebelum dan sesudah dilakukan senam wajah. Berat saliva (gr) kemudian dikonversi ke satuan ml untuk mendapatkan nilai kecepatan aliran saliva ( $\mathrm{ml} / \mathrm{menit})$.

Konversi dari gram ke milliliter dilakukan dengan rumus berikut (Antika, dkk, 2012):

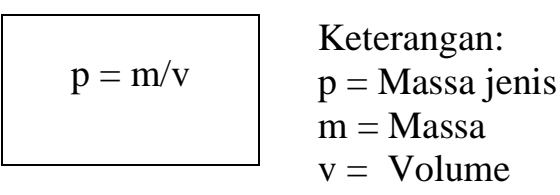


Uji normalitas menunjukkan data kecepatan aliran saliva sebelum dan sesudah senam wajah tidak terdistribusi normal ( $p$-value sebelum $=0,01$ dan $p$ value sesudah $=0,027$ ). Data kemudian dianalisis menggunakan wilcoxon signed rank test untuk melihat perbedaan kecepatan aliran saliva sebelum dan sesudah senam wajah.

\section{Hasil}

Tabel 1. Distribusi frekuensi rata-rata kecepatan aliran saliva

\begin{tabular}{cccc}
\hline \multicolumn{2}{c}{ Sebelum } & \multicolumn{2}{c}{ Sesudah } \\
\hline Kriteria & $\mathbf{n}(\%)$ & Kriteria & n (\%) \\
\hline Normal & $2(6,7)$ & Normal & $22(73,3)$ \\
Sedang & $17(56,7)$ & Sedang & $7(23,3)$ \\
Rendah & $11(36,6)$ & Rendah & $1 \quad(3,4)$ \\
\hline Mean & $\begin{array}{c}0,7 \\
\text { ml/menit }\end{array}$ & Mean & $\begin{array}{c}1,1 \\
\text { ml/menit }\end{array}$ \\
\hline
\end{tabular}

Tabel 1 menunjukkan distribusi kecepatan aliran saliva dengan keterangan Normal : 1-3 ml/menit., Lambat / sedang : 0,7-1 ml/menit dan Rendah : >0,7 $\mathrm{ml} / \mathrm{menit}$ (Almeida, 2008). Sebagian besar responden memiliki kecepatan aliran saliva sedang sebelum senam wajah $(56,7 \%)$ dan mayoritas memiliki kecepatan aliran saliva normal sesudah senam wajah $(73,3 \%)$.

\section{Tabel 2. Hasil Uji Wilcoxon}

\begin{tabular}{lc}
\hline Kecepatan aliran saliva & p-value \\
\hline $\begin{array}{l}\text { Sebelum dan sesudah } \\
\text { senam wajah }\end{array}$ & 0.006 \\
\hline
\end{tabular}

Tabel 2 menunjukkan bahwa hasil uji wilcoxon menunjukkan adanya perbedaan kecepatan aliran saliva pada lansia sebelum dan sesudah melakukan senam wajah $(p$-value $<0.05)$.

\section{Pembahasan}

Hasil uji wilcoxon menunjukan terdapat perbedaan antara kecepatan aliran saliva pada subjek sebelum melaksanakan senam wajah dan subyek setelah melaksanakan senam wajah $\quad(p$ value < 0.05). Hasil penelitian ini sesuai dengan penelitian yang dilakukan Ibayashi dkk di Jepang. Menurut Ibayashi (2008) senam wajah dapat menstimulasi sekresi saliva dan fungsi rongga mulut pada orang lanjut usia di Jepang. Senam dilakukan dengan latihan otot wajah, gerak lidah, dan memijat kelenjar saliva. Sekresi saliva meningkat secara signifikan setelah melakukan latihan fungsi merengangkan bibir, lidah dan pipi (Kyong, Kim, Yong, Fan and Kuung, 2016).

Hal ini dapat terjadi karena pelaksanaan senam wajah mendapat stimulasi mekanis yaitu latihan ekspresi otot wajah, latihan otot lidah dan pemijatan kelenjar saliva. Stimulasi yang diberikan dapat meningkatkan aliran sekresi saliva yang secara langsung mempengaruhi peningkatan volume saliva dalam rongga mulut (Indriana, 2010).

Sesuai dengan pernyataan Salmetrics dkk, (2015) dan Johansson dkk (2012) bahwa masa jenis saliva dapat diasumsikan $1 \mathrm{gr} / \mathrm{ml}$, maka kecepatan aliran saliva yang sudah dilakukan konversi pada kelompok sebelum melaksanakan senam wajah adalah $0,7 \mathrm{ml} /$ menit dan meningkat setelah senam wajah menjadi $1,1 \mathrm{ml} /$ menit.

Hal ini menunjukan nilai rata-rata kecepatan aliran saliva pada subyek sebelum senam wajah dan subyek setelah senam wajah sesuai dengan nilai sekresi saliva normal. Menurut Almeida dkk (2008), sekresi saliva normal pada saat tidak terstimulasi adalah antara 0,25 sampai $0,35 \mathrm{ml} /$ menit, sedangkan pada saat terstimulasi antara 1 sampai $3 \mathrm{ml} /$ menit. Rata-rata kecepatan aliran saliva saat terstimulasi yang termasuk dalam hiposalivasi adalah kurang dari $0,7 \mathrm{ml} / \mathrm{menit}$, sedangkan diatas $3 \mathrm{ml} /$ menit termasuk hipersalivasi.
(C) Jurusan Keperawatan Gigi Poltekkes Kemenkes Jakarta I J1. Wijaya Kusuma No. 47-48 Cilandak Jakarta Selatan, Indonesia email: jdht@poltekkesjakarta1.ac.id 


\section{Kesimpulan dan Saran}

Kesimpulan : senam wajah mempengaruhi kecepatan aliran saliva. Terdapat perbedaan kecepatan aliran saliva sebelum dan sesudah senam wajah pada lansia.

Saran : informasi tentang manfaat senam wajah terhadap kecepatan aliran saliva pada lansia diharapkan dapat diterapkan dalam program berkesinambungan yang berguna untuk menjaga kesehatan rongga mulut, terutama sebagai upaya pencegahan xerostomia.

\section{Daftar Pustaka}

Almeida. (2008.). Saliva Composition and Functions : 9(3), 72-80.

Dr. Veeresha K.L, Professor and Head, Dr. Goel Richa, Post Graduate Student, D. B. V. (2010). Xerostomia - A Common Problem of the Ederly. Journal of Orofacial \& Health Sciences, 1(3).

Ibayashi, H., Fujino, Y., Pham, T. M., \& Matsuda, S. (2008). Intervention study of exercise program for oral function in healthy elderly people. Tohoku Journal of Experimental Medicine, 215(3), 237-245.

Indriana, T. (2010). The Relationship Between Salivary Flow Rate and Calcium Ion Secretion in Saliva. Stomatognatic Jurnal Kedokteran Gigi, 7(2), 129-131.

Johansson, A. K., Jorkjend, L., Marthinussen, M. C., \& Johansson, A. (2012). A comparison of two clinical methods for measuring saliva in patients with Sjögren's syndrome. Acta Odontologica Scandinavica, 70(3), 251-254.

Kemenkes. (2013). Riset Kesehatan Dasar 2013. Badan Penelitian dan Pengembangan Kesehatan Kementerian Kesehatan RI.
L. Antika , E. Julianty, Miroah, A. Nurul, F. H. (2012). Pengukuran (Kalibrasi) Volume Dan Massa Jenis Alumunium. Spektra: Jurnal Fisika Dan Aplikasinya, 13(1), 22.

Lewapadang, W., Tendean, L. E. N., \& Anindita, P. S. (2015). Pengaruh Mengonsumsi Nanas (Ananas comosus) terhadap Laju Aliran Saliva pada Lansia Penderita Xerostomia. E-GIGI, $3(2)$.

Ligtenberg, A. J. M., Brand, H. S., Van Den Keijbus, P. A. M., \& Veerman, E. C. I. (2015). The effect of physical exercise on salivary secretion of MUC5B, amylase and lysozyme. Archives of Oral Biology, 60(11), 1639-1644.

Novi Afrianti, C. R. (2021). Faktor-Faktor Yang Mempengaruhi Kepatuhan Masyarakat Terhadap Protokol Kesehatan Covid-19. Jurnal Ilmiah STIKES Kendal, 11(1), 113-124.

Nunes, M. I. (2001). Quality of life in the elderly hypertensive. Journal of Cardiovascular Risk, 8(5), 265-269.

Rahayu, Y.C., dan Kurniawati, A. (2018). Cairan Rongga Mulut. Pustaka Panasea.

Salimetrics, L.L.C., SalivaBio, L. L. C. (2015). Saliva Collection and Handling Advice. Methods, 44(0), 1-15.

Study, P. (2009). Effects of Oral Health Care. 279286.

Utari, M. W., Purwanti, N., \& Yulianto, K. D. (2018). Pengaruh Senam Wajah terhadap Kecepatan Aliran Saliva. Universitas Gadjah Mada.
(C) Jurusan Keperawatan Gigi Poltekkes Kemenkes Jakarta I J1. Wijaya Kusuma No. 47-48 Cilandak Jakarta Selatan, Indonesia email: jdht@poltekkesjakarta1.ac.id

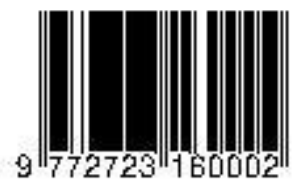

